\title{
The Impact of Road Infrastructure Development Projects on Local Communities in Peri-Urban Areas: the Case of Kisumu, Kenya and Accra, Ghana
}

\author{
Risper Sarah Khanani ${ }^{1}$ (D) Emmanuel Junior Adugbila ${ }^{1}$ (D) \\ Javier A. Martinez ${ }^{1}$ (D) Karin Pfeffer $^{1}$ (D)
}

Received: 30 March 2020 / Accepted: 4 September 2020 / Published online: 22 September 2020

(C) The Author(s) 2020

\begin{abstract}
Large-scale spatial planning and urban development projects have gained popularity in cities of the Global South. Such projects are being used to improve connectivity, scale up cities' competitiveness, and in return, attract investments. However, while road development changes peri-urban environments in the Global South cities, little attention is given to the consequences of road infrastructure in those areas. The objective of this paper is to investigate how the implementation of road infrastructure projects is transforming the socio-spatial landscapes and economic development, and how they affect social groups within the peri-urban areas of Kisumu (Kenya) and Accra (Ghana) cities, focusing on effects at the community level. The research employed a case study approach, using qualitative, quantitative and spatial methods to examine these socio-spatial and economic development dynamics. The findings show that, on the one hand, road infrastructure projects scaled up residential development, both in Kisumu and Accra, as the roads contributed to housing rents and land prices to increase and rendered peri-urban communities along them as attractive zones for real estate developers. Furthermore, accessibility to facilities and services improved. Also, in both cities, the road improvements fuelled employment opportunities. Conversely, in both cities, the road infrastructure projects led to gentrification and therefore to the displacement of poor residents into the hinterlands, which changed the social fibre and integration to a certain degree. The road infrastructure projects benefitted the rich, who own land at the expense of the poor. The findings that the impacts of road infrastructure appear to differ in locational context and class of individuals within peri-urban areas make us suggest that place-based and people-based policies need to be combined to address the consequences of road infrastructure projects.
\end{abstract}

Keywords Road infrastructure projects · Peri-urban areas · Interaction and integration . Development dynamics $\cdot$ Kisumu $\cdot$ Accra

\section{Introduction}

Large-scale spatial planning and urban development projects are increasingly becoming popular in transforming landscapes in rapidly urbanizing cities of the Global South. 
Most governments in the Global South are using such projects to scale up their cities' competitiveness, requiring structuring and re-structuring of their road networks, and in return, attract investments. These large-scale projects, for instance road infrastructure projects, touch on multiple stakeholders, possibly leading to all kinds of changes in adjacent areas (Erkul et al. 2016; Oviedo Hernandez and Dávila 2016). However, the attempt of scaling- up the city and making it competitive sometimes fails to consider the needs of the affected citizens during the infrastructural development (Brussel et al. 2019; Aoun 2016). Construction of roads, whether new or upgrading of existing ones, is presumed to have a range of impacts on the population, urban form, economic status and environment (Mackett and Edwards 1998). The impacts may be both positive and negative depending on the situated social, spatial, economic and environmental context.

Studies have shown that due to availability of land at low cost and nearness to jobs in cities, peri-urban areas have become the destination for infrastructural development (Ravetz et al. 2013; Simon et al. 2004; Thuo 2010). Such infrastructural development has been found to improve mobility enhancing accessibility to jobs, social facilities and services such as schools and hospitals as well as an increased market for agricultural goods and services (Pradhan and Bagchi 2013; Gibson and Rozelle 2003). It has also been presumed that new roads lead to improved living conditions of those living near such projects through possibilities for social development, economic opportunities and enhancement of the welfare of communities. They were also seen to have the power to promote interactions among residents, especially those who are engaged in commerce (Doan and Oduro 2012). However, road infrastructure projects are also endowed with negative socio-economic changes in certain communities or for specific social groups, increasing income disparity as they offer limited benefits to the poor or further disintegrating the urban form into urban fragments (Porter 2011; Wiegand et al. 2017). This suggests that road infrastructure projects tend to benefit the rich, who own land and are further able to access additional land due to increase in land values, at the expense of the poor (Porter 2011; Leinbach 2000).

Additionally, road infrastructure projects also tend to lead to active land-use changes in many Global North and South cities, specifically, the breaking up of the urban environment into smaller areas with limited or no interaction between them, and with no relationship that permits cohesion and coherence (Balbo and Navez-Bouchanine 1995; Landman 2011; Al Shawish 2015; Bocarejo et al. 2015). Therefore, both social and spatial differentiations among social groups may emerge following road developments. This is likely to aggravate segregation, gentrification and polarisation enhancing existing inequalities (Manderscheid and Bergman 2008; Bocarejo et al. 2015). Road improvements in peri-urban areas of most Global South cities are also seen as a recipe for the displacement of the poor due to gentrification processes (Briggs and Mwamfupe 2000). Empirical evidence shows gentrification in the Global South as direct and indirect displacement of low-income groups by the rich as a result of an increase in property rentals and urbanization (Kombe 2005; Davidson and Lees 2005; López-Morales 2015; Krijnen 2018).

Studies on peri-urban areas have given little attention to the consequences of road infrastructure projects in local communities of Global South countries. Road infrastructure projects in such countries are mainly critiqued for their impacts on urban sustainability at the city level (Kennedy 2015). Thus, there is a need for further empirical studies on socioeconomic and spatial ramifications of road infrastructural expansions in peri-urban areas (Doan and Oduro 2012), and especially at the community level. Therefore, the main question addressed in this paper is how road infrastructure projects shape the urban fabric 
and associated processes, and how they affect social groups within the peri-urban areas of Kisumu (Kenya) and Accra (Ghana) cities, focusing on effects at the community level. By looking at three dimensions derived from the literature related to the urban fabric and its associated processes such as social changes, spatial (residential) dynamics and economic processes for different social groups, the paper provides empirical insights on potential consequences of road infrastructure projects in these two Global South cities. Global South countries in this paper refer to low to middle-income countries.

In the subsequent sections, the paper first provides historical background on transport infrastructures and describes the theories on which the conceptual framework is anchored. This is followed by the methodology, case study areas, results and discussion of the results. In the conclusion section, this paper summarizes the main impacts of road infrastructure projects in transforming the socio-spatial landscapes and economic development and their effects on local communities in the peri-urban areas and reflects on how empirical insights can inform policy formulation.

\section{Background and Related Work}

\section{Historical Background}

Road infrastructure projects have massive investments since they have been used to achieve economic prosperity through haulage of goods and services from one place to another (Jedwab and Moradi 2016). In Sub-Sahara Africa, road infrastructure presently remains the means of conveying about $75 \%$ of freights and passengers (Beuran et al. 2015). Considering that about $50 \%$ of the roads in the Sub-Sahara region are yet to be constructed implies that road infrastructure development remains on the top list of physical infrastructure developments in such cities, potentially impacting the socioeconomic and physical environment of the cities and their peri-urban areas (Gachassin et al. 2010; Cobbinah et al. 2015).

From a historical point of view of the Global South countries, especially Kenya and Ghana, transportation infrastructures show some contrasting outcomes though with a few similar scenarios. In both countries, road infrastructure projects are on the increase resulting in social and spatial heterogeneities, particularly within the peri-urban areas. These include growing inequalities, exclusion, housing, safety and security (UNHabitat 2016). This has also led to competition between newcomers and old inhabitants for land and other natural resources, thus affecting living conditions, especially of the very poor (Yankson and Gough 1999; ASIRT 2014).

According to Jedwab et al. (2017), the Kenya - Uganda, railroad, "the lunatic line", was built between 1896 and 1901 to connect landlocked and relatively prosperous Uganda to the port of Mombasa in Kenya. Kenya was a transit territory and the railroad followed the route that minimized construction costs. Thus, the railroad traversed sparsely settled areas that had no freight to transport. However, plots near the railroad were offered to European settlers to create an agricultural export industry. This also established the general urban patterns in Kenya, where urban centres sprouted along the main railroad route. The contemporary spatial arrangement of economic activity depends on these earlier infrastructure investments (Jedwab et al. 2017). The Kenya-Uganda railroad collapsed between the 1960 s and 1970s and paved way to other forms of transport like road infrastructure 
especially away from the railroad (Jedwab et al. 2017). In Kenya, a contemporary emphasis has been given to the implementation of the Northern Corridor Transport Improvement Project (NCTIP). The transport corridor aims at connecting Kenya nationally and transnationally. This would also correct the region's history of socio-economic marginalization that was experienced during colonialism.

In Ghana, before the 1920s, the railroad was the primary mode of transportation of goods by the colonial authorities from the hinterlands to the coastal zones. Road infrastructure became the first complementary transport mode in the 1920s serving as feeders to the railway system (Jedwab and Moradi 2016). Road infrastructure came to the fore with the implementation of the Tarmet Program to aid in the transportation of cocoa for export. The British colonial administration consolidated its dominance in trade and military through transportation infrastructures. The aim was to link the hinterlands of the country to the coastal areas, to move goods and to quickly dispatch troops to its resistance areas (Jedwab and Moradi 2016). Post-colonial governments have continued to invest in road infrastructure to further open up the country, such as the Accra-Kasoa road that links Greater Accra and Central regions to boost trading activities by reducing travel time (Jedwab and Moradi 2016). Colonialists planned railroads in the two cities to link the hinterlands to the coastal areas. In Kenya, the railroad was majorly for transportation of goods and raw materials but in Ghana it was substantially used to transport troops to quash local resistance.

\section{Related Work / Conceptual Approach}

In order to answer the empirical question of how road infrastructure shapes the urban fabric and the associated processes, and how it impacts on different social groups at the community level in Kisumu and Accra, the study employed a conceptual approach based on analytical categories of social, spatial and economic aspects (Fig. 1). This conceptual framework is anchored in theories of urbanization and the theory of sociospatial integration, building on arguments by Bodo (2019), Woltjer (2014), Ruiz-Tagle (2013) and Allen (2003). According to Woltjer (2014), peri-urban areas have been characterized by their changing local economic and employment patterns from rising land values and dynamic land uses. These kinds of changes have been observed in many peri-urban and urban areas of Global South countries resulting from rapid urbanization, and they may be positive or negative (Bodo 2019; Woltjer 2014). The spatial changes that emerge during urbanization encompass an increase in residential development, land cover conversions or changes in land uses. Social changes likely to emerge include social disintegration. Economic ones include a shift from agriculturally-based economic activities to those of higher productivity and infrastructures like roads, with the possibility of employment opportunities (Allen 2003; Woltjer 2014). Ruiz-Tagle (2013) argued that socio-spatial integration is characterized by four dimensions, namely physical, functional, relational and symbolic which are about physical proximity, access to opportunities, social groups' interaction and identity. The dimensions are likely to help in enhancing the integration of residents between and within communities. Accordingly, in this study we considered social, spatial and economic aspects of development.

Based on the arguments from the literature on these theories, we developed a conceptual framework where certain dimensions, relevant for the context of our case studies, and their relations are depicted (see Fig. 1). The dimensions were used to measure the possible 


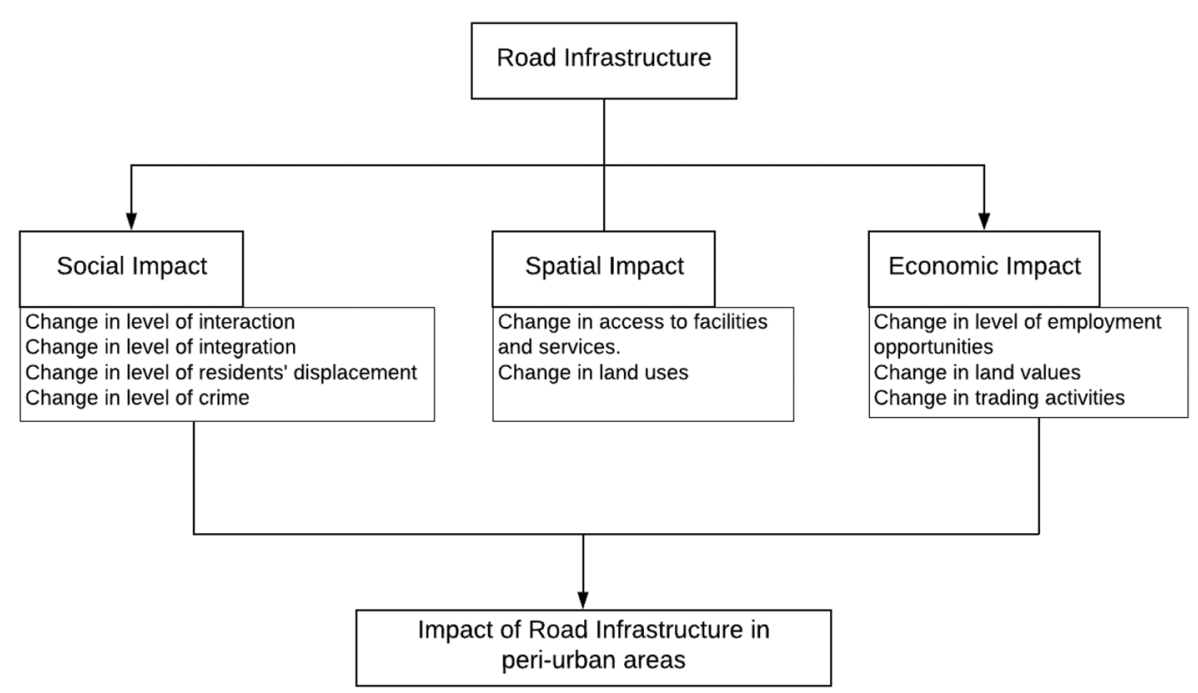

Fig. 1 Conceptual approach (Source: Authors' construct, 2019, based on literature review)

impacts of road infrastructure projects in the studied communities which may inform community wellbeing of different social groups.

\section{Methods and Materials Used}

The paper uses a mixed-methods and a comparative case study approach. It integrates qualitative, quantitative and spatial methods where the data is collected and analyzed in a concurrent way to reach completeness and a more comprehensive account (Bryman 2006). We selected two case studies (Kisumu in Kenya and Accra in Ghana) based on their geographic locations regarding road infrastructure projects and contrasting characteristics concerning social, spatial and economic dynamics. In Kisumu city, Kenya, the study analyzed Tom Mboya and Obunga communities, adjacent to a bypass road which was the main focus for the assessment of interaction among residents and subjective quality of life, ${ }^{1}$ reflecting on their satisfaction with domains in life and experiences within the socio-economic and physical environment that they live in. In Accra city, Ghana, the study focused on Tuba and Mataheko communities lying opposite each other. The analytical dimensions and associated indicators are presented in Table 1.

The primary data collection took place between September and November 2018 and included Key informant Interviews (KIIs), Focus Group Discussions (FGDs), questionnaires, walking interviews, and field observations. Nine KIIs were conducted in Kisumu and seven in Accra, to obtain opinions from academia, residents, County, government ministry officials, experts and agencies on road infrastructure and residential development. Additionally, in Kisumu city, eight walking interviews with residents

\footnotetext{
${ }^{1}$ Senlier et al. (2009) define Quality of life as the relation between perceptions and the feelings of people, and their experiences within the space they live in, which makes an individual's life to be desirable or undesirable with different domains in life.
} 
Table 1 Indicators to measure the impact of road infrastructure projects

\begin{tabular}{|c|c|c|c|c|}
\hline Dimensions & Indicators & Description & Measured by & $\begin{array}{l}\text { Supporting } \\
\text { literature }\end{array}$ \\
\hline \multirow[t]{2}{*}{ Social } & \multirow[t]{2}{*}{ 1. Change in level of } & $\begin{array}{l}\text { 1. Perception about } \\
\text { Social networks } \\
\text { (Support from } \\
\text { friends, } \\
\text { neighbours and } \\
\text { relatives) and } \\
\text { social interactions. }\end{array}$ & $\begin{array}{l}\text { interaction/integration } \\
\text { Lusher et al. } 2010\end{array}$ & $\begin{array}{l}\text { 1. Relationship } \\
\text { of residents } \\
\text { within and } \\
\text { between } \\
\text { communities. }\end{array}$ \\
\hline & & $\begin{array}{l}\text { 2. Change in level of } \\
\text { resident's } \\
\text { displacement }\end{array}$ & $\begin{array}{l}\text { 2. Residents forced to move } \\
\text { into hinterland. }\end{array}$ & $\begin{array}{l}\text { 2. Perception } \\
\text { about } \\
\text { displacement }\end{array}$ \\
\hline $\begin{array}{l}\text { 3. Change } \\
\text { in level } \\
\text { of crime }\end{array}$ & $\begin{array}{l}\text { 3. Rate of robbery, } \\
\text { stealing }\end{array}$ & $\begin{array}{l}\text { 3. Residents } \\
\text { perception of } \\
\text { crime in the } \\
\text { neighbourhood }\end{array}$ & $\begin{array}{l}\text { (Sabatini and Salcedo } 2007 \\
\text { and Khaef \& Zebardast, } \\
\text { 2016) }\end{array}$ & \\
\hline \multirow[t]{2}{*}{ Spatial } & $\begin{array}{l}\text { 4. Change in access to } \\
\text { facilities \& } \\
\text { services }\end{array}$ & $\begin{array}{l}\text { 4. Access to } \\
\text { electricity, water, } \\
\text { schools, transport, } \\
\text { health facilities } \\
\text { etc. }\end{array}$ & $\begin{array}{l}\text { 4. Improved access to } \\
\text { facilities and services }\end{array}$ & \multirow[t]{2}{*}{$\begin{array}{r}\text { (Sirgy, Rahtz, \& } \\
\text { Swain, 2006) }\end{array}$} \\
\hline & $\begin{array}{l}\text { 5. Change in land } \\
\text { uses }\end{array}$ & $\begin{array}{l}\text { 5. New urban forms } \\
\text { emerging }\end{array}$ & $\begin{array}{l}\text { 5. Improved quality of } \\
\text { buildings (built-up } \\
\text { typology) }\end{array}$ & \\
\hline \multirow[t]{3}{*}{ Economic } & $\begin{array}{l}\text { 6. Change in level of } \\
\text { employment } \\
\text { opportunities }\end{array}$ & $\begin{array}{l}\text { 6. Access to } \\
\text { employable } \\
\text { opportunities. } \\
\text { Access to income } \\
\text { generating } \\
\text { activities. }\end{array}$ & $\begin{array}{l}\text { 6. Change in living conditions } \\
\text { of residents }\end{array}$ & $\begin{array}{l}\text { (Sabatini 2006; } \\
\text { Ruiz-Tagle } \\
\text { 2013) }\end{array}$ \\
\hline & $\begin{array}{l}\text { 7. Change in land } \\
\text { values }\end{array}$ & 7. Land values & 7. Current land values & \multirow{2}{*}{$\begin{array}{l}\text { (Sirgy et al., } \\
\text { 2006; Blanc, } \\
\text { 2010) }\end{array}$} \\
\hline & $\begin{array}{l}\text { 8. Change in trading } \\
\text { activities }\end{array}$ & $\begin{array}{l}\text { 8. Access to goods } \\
\text { and services in } \\
\text { communities. }\end{array}$ & $\begin{array}{l}\text { 8. Change in access to goods } \\
\text { and services }\end{array}$ & \\
\hline
\end{tabular}

Scale of Measurement: Likert Scale of 1-5 points, where 1-very high/very far/strongly agree and 5- very low/ very close/strongly disagree

(four men and four women selected randomly) were conducted to assist in an in-depth understanding of the perceived change in the studied communities. In contrast, in Accra city, one FGD was held in each community comprising members who had lived in the communities and witnessed the road construction considering the road was constructed over ten years. The FGDs (six men and four women) were selected by contacting the assembly members ${ }^{2}$ of the communities to reach out to opinion and community leaders who had adequate knowledge about the Accra-Kasoa road expansion. Questionnaires were administered to household heads, above 18 years, both men and women who had lived in the communities for at least five years or longer during the road construction,

\footnotetext{
${ }^{2}$ Assembly members refer to persons elected at the local government to perform duties and responsibilities as prescribed by the 1992 Constitution of Ghana and Local Government Act 1993 (Act 463) towards promoting of local level development within their respective electoral areas.
} 
for the Kisumu case, and at least ten years or longer for the Accra case (as the road projects started in 2013 and 2008 respectively).

Random sampling was used to select questionnaire respondents. In Kisumu, respondents were selected from each administrative unit for Obunga and each estate for Tom Mboya community. A total of 239 questionnaires were administered (111 in Tom Mboya, 128 in Obunga). In Accra, a total of 310 questionnaires were administered in the household survey, 155 respondents each in Tuba and Mataheko to obtain their perceptions of the road expansion on their livelihoods. The household questionnaires were collected using Open Data Kit (ODK) Collect for Kisumu case and KoBoCollect for Accra case. The mobile applications choice was based on ease of use and the familiarisation by the data collectors. The variables adopted for analyzing the residents' perceptions were selected based on the local conditions of the studied communities. This study used household heads as a unit of data collection and community as a unit of analysis in determining interaction/integration, accessibility to facilities, land-use changes, employment opportunities and land value dynamics between different social groups within the studied communities (Table 2).

The secondary sources were aerial images/satellite imagery (sourced from google maps, 2018 (Kisumu and Accra)), population data (from Kenya National Bureau of Statistics and Pamoja Trust (Kisumu) and Ghana Statistical Service (GSS)), road data (shapefiles from Kisumu Physical Planning office and Accra Planning Authority), and boundary data of the communities (shapefile derived from ArcGIS online for both Kisumu and Accra) as well as grey-literature and reports from relevant departments (for literature review). The aerial images were used to classify the studied communities as "better-off" and "worse-off" in terms of the spatial characteristics with field validation in both cities and to analyze the two moments, "before and after" of the road projects.

Data were analyzed concurrently employing qualitative, quantitative and spatial tools to arrive at a complete and comprehensive understanding of the impacts of road expansion in the local communities (Bryman 2012). The qualitative data were coded and analyzed using ATLAS.ti software to understand the social and economic impacts which may have emerged in the communities over time due to the road projects. The quantitative data were analyzed using descriptive statistics in Software Package for Social Science (SPSS), for better understanding of the perceived impacts. The spatial data analysis was done in ArcGIS for visualization (maps) of physical land-use changes which had emerged overtime on studied communities as identified through the visual image interpretation, interviews and field observations.

Table 2 Methods of data collection in the two cases

\begin{tabular}{lll}
\hline Methods of data collection & Kisumu & Accra \\
\hline Key informant interviews (KII) & 9 & 7 \\
Walking interviews & 8 & $\mathrm{x}$ \\
Focus Group Discussion (FGD) & $\mathrm{x}$ & 2 \\
Questionnaire & 239 & 310 \\
\hline
\end{tabular}

$\mathrm{x}$-This method of data collection was not considered 


\section{Case Study Areas}

Rapid urbanization in Kenya has made Kisumu city to continue attracting investments and large-scale projects, with the most recent ones being road infrastructure projects to ease transport. In Ghana, Accra city is transforming in terms of spatial and socioeconomic dynamics. The Kisumu road infrastructure project (also known as Nyamasaria-Airport Bypass, constructed between 2013 and 2016) is a sub-section of the Northern Corridor Transport Improvement Project (NCTIP), an international road to transit goods being implemented in Kenya (Fig. 2a). The NCTIP is a mega road project that links the Democratic Republic of Congo, Burundi, Rwanda and Uganda, and starts from Mombasa in Kenya and covers more than 2000 km (Gichaga 2017). In the case of Accra, the road infrastructure is a toll road highway expanded in 2008 by the Government of Ghana with donor financial support to ease traffic from Greater Accra to Central regions (Fig. 2b) and to facilitate the movement of goods and people between the regions and beyond as it also connects Ghana to its neighbouring country, Ivory Coast (Ardayfio-Schandorf et al. 2012).

When the railway line arrived in Kisumu in 1901 many people migrated into the town. In 1908, Kisumu was struck by the bubonic plague, which resulted in the zoning of residential areas (CRDC 2016). According to Anderson (2016), the British colonial township board zoned the residential areas of the city into blocks; European and Asians were zoned in one block, which included Tom Mboya and Milimani communities. The other blocks were left for Africans and Arabs, and they included Obunga and Nyalenda, among others. The social divisions of the city during colonialism were reflected in the racial location of residential quarters and this is still evident in some estates.

Accra became an urban centre in 1877 when the British colonial administration relocated their capital from Cape Coast to Accra. This was due to varied reasons, including health-related and geographical factors. Cape Coast was perceived to have native-born diseases which could affect colonial staff and had a shallow ocean berth hindering vessels used for transporting raw materials for export to Europe and beyond from docking (Grant and Yankson 2003). Since then, Accra grew to be an economic hub and a cosmopolitan city attracting a fishing community to the cosmopolitan type, which later saw infrastructural growth and expansion over its peri-urban areas (Grant and Yankson 2003). This physical growth of Accra has led to the emergence of peri-

a

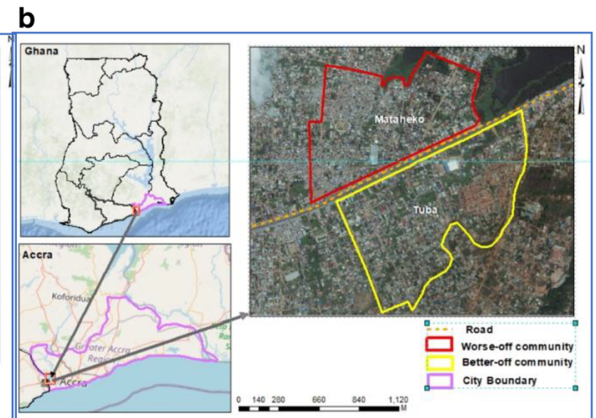

Fig. 2 a Contextual location of Kisumu communities. b Contextual location of Accra communities. Source: World ocean base \& Google Earth, 2018 and Author, 2018. Boundary data: ArcGIS online (Kisumu ward boundaries, 2016) 
urban towns like Dodowa, Aburi and Kasoa, which are functionally connected to Accra Central infrastructurally.

The two cases studied four communities with different degree of living conditions (quality of life). For the case of Kisumu, one of the communities is Tom Mboya (planned $^{3}$ ) and the other is Obunga (unplanned) (See Fig. 2a). Considering the prevailing socio-economic and physical conditions, Tom Mboya and Obunga can also be categorized as a "better-off" and a "worse-off"4 community respectively. In the case of Accra, both communities, Tuba and Mataheko, are unplanned, since they are in periurban Accra, in a transition zone that does not have planning schemes (Fig. 2b) and they are also categorized as a "better-off" and a "worse-off" community respectively. The social, spatial and economic dimensions identified from the literature were used in measuring the impacts of the road infrastructure on different social groups across the communities in both cases.

\section{Results}

\section{Characteristics of the Respondents}

The study comprised of 549 respondents, of which 239 were from Kisumu, Kenya while 310 were from Accra, Ghana. For the Kisumu case, most of the respondents in the better-off community (Tom Mboya) were men (53\%). Contrary, most of the respondents in the worse-off community (Obunga) were women $(60 \%)$. For the Accra case, $52 \%$ of the respondents in the better-off community (Tuba) were men while in the worse-off community (Mataheko), $57 \%$ were women (See Table 3).

In Obunga community, $58 \%$ of the respondents had attained primary school level of education. However, for Tom Mboya community, those with university level of education registered the highest percentage (32\%). In Accra city, $41 \%$ and $39 \%$ of the respondents in Tuba and Mataheko had education up to secondary and post-secondary level respectively, 39\% in Tuba and 41\% of them in Mataheko had primary level of education and the same percentage $(20 \%)$ of the respondents in Tuba and Mataheko with the highest education level of post-graduate degree (Table 3). The analysis gives a general overview of the literacy levels of the residents in both communities, which surmises that the studied communities likely had lower to middle -income residents. Considering age cohorts, the majority of the respondents in Kisumu were between 35 and 54 years $(61 \%)$ in Tom Mboya, and between 18 and 34 years $(56 \%)$ in Obunga. While in Accra, majority of the respondents were between 35 and 54 years in both communities $(65 \%$ in Tuba and $73 \%$ in Mataheko).

\footnotetext{
${ }^{3}$ Planned neighborhoods are developed under government regulatory framework and as per the contextual urban planning guidelines (Kola et al. 2015). Whereas, unplanned neighborhoods develop with no proper planning and not directed by any governing framework, (Wagah et al. 2017).

4 "Better-off" areas are neighbourhoods with above average income residents who have better housing conditions together with good quality facilities. Whereas "worse-off" areas are neighbourhoods mostly with low-income residents poor housing conditions and facilities (Huby et al. 2009; Martínez 2009).
} 
Table 3 Socio-demographic characteristics of respondents

\begin{tabular}{|c|c|c|c|c|c|}
\hline \multirow[t]{2}{*}{ Characteristics } & & \multicolumn{2}{|l|}{ Kisumu } & \multicolumn{2}{|l|}{ Accra } \\
\hline & & $\begin{array}{l}\text { Tom Mboya } \\
(N=111)\end{array}$ & $\begin{array}{l}\text { Obunga } \\
(N=128)\end{array}$ & $\begin{array}{l}\text { Tuba } \\
(N=155)\end{array}$ & $\begin{array}{l}\text { Mataheko } \\
(N=155)\end{array}$ \\
\hline \multirow[t]{2}{*}{ Gender } & Male & $53 \%$ & $40 \%$ & $52 \%$ & $43 \%$ \\
\hline & Female & $47 \%$ & $60 \%$ & $48 \%$ & $57 \%$ \\
\hline \multirow[t]{3}{*}{ Education level } & Primary & $19 \%$ & $58 \%$ & $39 \%$ & $41 \%$ \\
\hline & Secondary \& post-secondary & $49 \%$ & $39 \%$ & $41 \%$ & $39 \%$ \\
\hline & University & $32 \%$ & $3 \%$ & $20 \%$ & $20 \%$ \\
\hline \multirow[t]{3}{*}{ Age cohort } & 18-34 Years & $32 \%$ & $56 \%$ & $15 \%$ & $12 \%$ \\
\hline & 35-54 Years & $61 \%$ & $34 \%$ & $65 \%$ & $73 \%$ \\
\hline & 55 Years and above & $7 \%$ & $10 \%$ & $20 \%$ & $15 \%$ \\
\hline
\end{tabular}

\section{Impacts of Road Infrastructure Development Projects on Selected Communities in Kisumu and Accra}

This paper premises its results on the before and after situation concerning social, spatial and economic impacts of the road infrastructure projects between and within the studied communities. The identified potential impacts were grouped into positive and negative impacts, depending on how beneficial they were to the interaction and integration processes, and subjective quality of life of the residents in the studied communities as summarised in Table 5 .

\section{Social Impact}

The road infrastructure projects have different impacts on social integration in the two cities. The dimension of social impact dwelt on social interaction and integration between residents and within communities, being measured by social networks and residents' perception. Social networks in the selected communities of Kisumu city entailed respondents feeling at home in their neighbourhoods, receiving support from friends, relatives and neighbours (Table 1). In Kisumu, the road enhanced social interactions amongst residents of the researched communities and opened up connectivity between and within communities as also expressed by an interviewee from Maseno University in Kisumu: “... the Bypass has also led to the opening up of some streets within Obunga like Pamba road which again encourages some residents from Tom Mboya to go through Obunga and join Kakamega road." However, in Accra, residents in the studied communities perceived a decline in social integration due to the springing up of gated communities replacing non-gated ones after the road expansion. A member of an FGD in Mataheko in Accra city mentioned that: "Before the road was expanded we could organize outdoor games like football games with other communities and we play together and go our various ways without any troubles. After this road expansion, all the residential buildings are self-contained types which keep households from interacting easily with one another as it was the case before the expansion with 
the predominantly compound types ${ }^{5}$ of buildings". Some residents within Mataheko perceive that with the road expansion a lot of middle-income people came to settle in the community because of reduction in traffic to and out of the community to Accra central, resulting in less interaction.

Additionally, in both Kisumu communities, insecurity reported beneath overpasses of the bypass road to non-motorized users especially at night, may be attributed to the bypass design and absence of lights beneath the overpasses as stated by resident's association official from Obunga: "...the bypass road has also contributed to insecurity, there is a flyover (overpass) where thieves and muggers hide at night and attack people. The place is a bit dark at night, so thieves take advantage” (Table 5). Similarly, in Tuba and Mataheko in Accra, residents perceived that the road project led to an increase in crime rate. Activities such as pickpocketing surfaced in Tuba where most of the rich live. Although in Mataheko, cases of snatching of bags from women by criminals on motorbikes were also reported. A member of the FGD in Mataheko in Accra city expressed that: "Women in this community had the bags snatched by criminals on motorbikes after the road expansion but before the road expansion this was not present in our community like that. Before the expansion of the road, these kinds of things were not present in this town". FGDs in Tuba and Mataheko alluded to these criminal activities being present in their communities after the road expansion.

\section{Spatial Impact}

The spatial dynamics which emerged in the studied communities in Kisumu and Accra due to the expansion of the roads as expressed in the interviews of experts and agencies included: high degree of residential development, changes in access to facilities and services, change in land uses, and informal developments. Interviews and FGDs in Kisumu and Accra cities revealed that the road expansion led primarily to improved access to facilities like education and health facilities, recreational areas, religious and cultural institutions, water and electricity. Respondents in Tom Mboya and Obunga in Kisumu perceived low accessibility to facilities before, and high accessibility after road expansion as shown through mean scores in Table 4, for instance, high accessibility to education facilities after road expansion, with mean scores of 3.59 and 3.78 respectively. The increase in perceived accessibility after road expansion was registered across the five dimensions in both communities in Kisumu (Table 4). Most of the interviews agreed with the perception of the respondents about improved accessibility in both communities with an interviewee from Maseno University in Kisumu stating that; "The opening up of the Bypass has promoted accessibility in that you can easily go through Obunga or Tom Mboya and access the various activity zones that one may want to visit in that area. So, we can say that the Bypass has promoted accessibility...".

Similarly, respondents in Tuba and Mataheko in Accra city also perceived high access to primary schools after the road expansion, with mean scores of 4.16 and 4.57 respectively (Table 4). The Kisumu bypass improved not only accessibility to basic services and facilities within both communities, but also opened up their connectivity to other neighbouring communities, even beyond those that were studied.

\footnotetext{
${ }^{5}$ Compound house is a type of multi-building with a common entrance where several households live in different rooms but share the same yard and other sanitary facilities such as bath and toilets.
} 
Table 4 Respondents' perception on access to facilities in Tom Mboya and Obunga in Kisumu; Tuba and Mataheko in Accra before and after road expansion

\begin{tabular}{|c|c|c|c|c|c|}
\hline \multirow[t]{2}{*}{$* \mathrm{a}$} & & \multicolumn{2}{|c|}{ Tom Mboya $(N=111)$} & \multicolumn{2}{|c|}{ Obunga $(N=128)$} \\
\hline & & Before & After & Before & After \\
\hline \multirow[t]{2}{*}{ Education } & Mean & 2.73 & 3.59 & 2.29 & 3.78 \\
\hline & Standard Deviation & 1.04 & 0.836 & 0.723 & 0.822 \\
\hline \multirow[t]{2}{*}{ Health } & Mean & 2.74 & 3.62 & 2.38 & 3.71 \\
\hline & Standard Deviation & 0.997 & 0.763 & 0.754 & 0.862 \\
\hline \multirow[t]{2}{*}{ Recreation } & Mean & 2.86 & 3.59 & 2.50 & 3.50 \\
\hline & Standard Deviation & 1.018 & 0.779 & 0.721 & 0.813 \\
\hline \multirow[t]{2}{*}{ Church/Mosque } & Mean & 2.82 & 3.62 & 2.58 & 3.53 \\
\hline & Standard Deviation & 0.94 & 0.742 & 0.706 & 0.813 \\
\hline \multirow[t]{2}{*}{ Cultural Institutions } & Mean & 2.88 & 3.54 & 2.52 & 3.48 \\
\hline & Standard Deviation & 0.951 & 0.774 & 0.742 & 0.823 \\
\hline \multirow[t]{2}{*}{$* \mathrm{~b}$} & & \multicolumn{2}{|c|}{ Tuba $(N=155)$} & \multicolumn{2}{|c|}{ Mataheko $(N=155)$} \\
\hline & & Before & After & Before & After \\
\hline \multirow[t]{2}{*}{ Primary schools } & Mean & 2.53 & 4.16 & 2.45 & 4.57 \\
\hline & Standard Deviation & 0.89 & 0.82 & 1.08 & 0.59 \\
\hline \multirow[t]{2}{*}{ Health facilities } & Mean & 2.34 & 3.52 & 2.46 & 4.00 \\
\hline & Standard Deviation & 0.82 & 0.93 & 1.04 & 0.91 \\
\hline \multirow[t]{2}{*}{ Public transport } & Mean & 3.05 & 4.08 & 3.35 & 4.24 \\
\hline & Standard Deviation & 1.05 & 0.68 & 0.68 & 0.72 \\
\hline
\end{tabular}

\footnotetext{
*a Likert scale 1-5 where one $(1)=$ Very low accessibility and five $(5)=$ Very high accessibility (Kisumu)

*b Likert scale $1-5$ where one $(1)=$ Very far and five $(5)=$ Very close (Accra)

(Bold: mentioned in the text). Note (Dimensions used in measuring perceived access to facilities differ due to the context of the two different cases)
}

The Accra city road project turned the small town of Kasoa into a cosmopolitan town "overnight" as it served as an impetus for the influx of both high and middleincome people into the peri-urban communities, and this changed the urban form of residential development patterns. According to Ardayfio-Schandorf et al. (2012), and as also given by the interviewee from the University of Ghana, “...in 1970 and 1984, the population of Kasoa was 863 and 2,597 respectively, but it reached 34,719 in 2000 and 69,834 in 2010". This meant that Kasoa was growing leaps and bands and the road project was considered one of the reasons; however, this may be due to other reasons such as population growth. Interviews and FGDs pointed to an upscale and improvement of the physical development of the studied communities after the road expansion.

It was observed that changes were on-going within the residential communities; both social and physical changes were visible, after the road expansion in Kisumu city. In Tom Mboya, demand for land increased, leading to changes in residential densities and sub-divisions of land parcels. An emerging trend was also that some residents were leasing out their residential houses for commercial use and relocated to peri-urban areas (Fig. 3a). According to the Kisumu city Physical Planner, “... these areas were originally zoned for single-family residential, low density as per the 1984 Structure Plan of the Kisumu city, the changes may be partly attributed to road project. The 
scarcity for office space within the Central Business District (CBD) largely influenced the leasing out of the residential houses for commercial use which include; hotels, health facilities, learning institutions and offices for Non-Governmental Organizations". Similarly, the quality of housing in Obunga community in Kisumu city was also changing with middle standard buildings springing up as was observed during the walking interviews (Fig. 3b).

In Accra city the conversion of land uses emerged in the studied communities after the road project. Interviews and FGDs revealed that agricultural lands were converted into residential and commercial uses over time. Residential uses, mainly those closer to the road, were converted into commercial uses such as stores, shops, stalls and fuel stations among others by investors. Survey respondents, FGD participants and interviewees all stressed that the road drove in more residents from Accra central into the studied communities. After the road expansion, some residents from Accra central started moving into the communities to live there. Hence some parcels of farmlands were being acquired and converted into residential uses by real estate developers (Fig. 4). The Accra city road project encouraged the emergence of gated and informal settlements as revealed during the FGDs and key informant interviews.

\section{Economic Impact}

The Kisumu and Accra cities road infrastructure projects brought employment opportunities to residents of the studied communities. In Kisumu, not only did businesses improve after the implementation of the bypass road but also the operation of motorcycles to ferry people from one place to another increased. Small-scale businesses like welding, vegetable vending, among others, sprung up along the Bypass. In Accra,

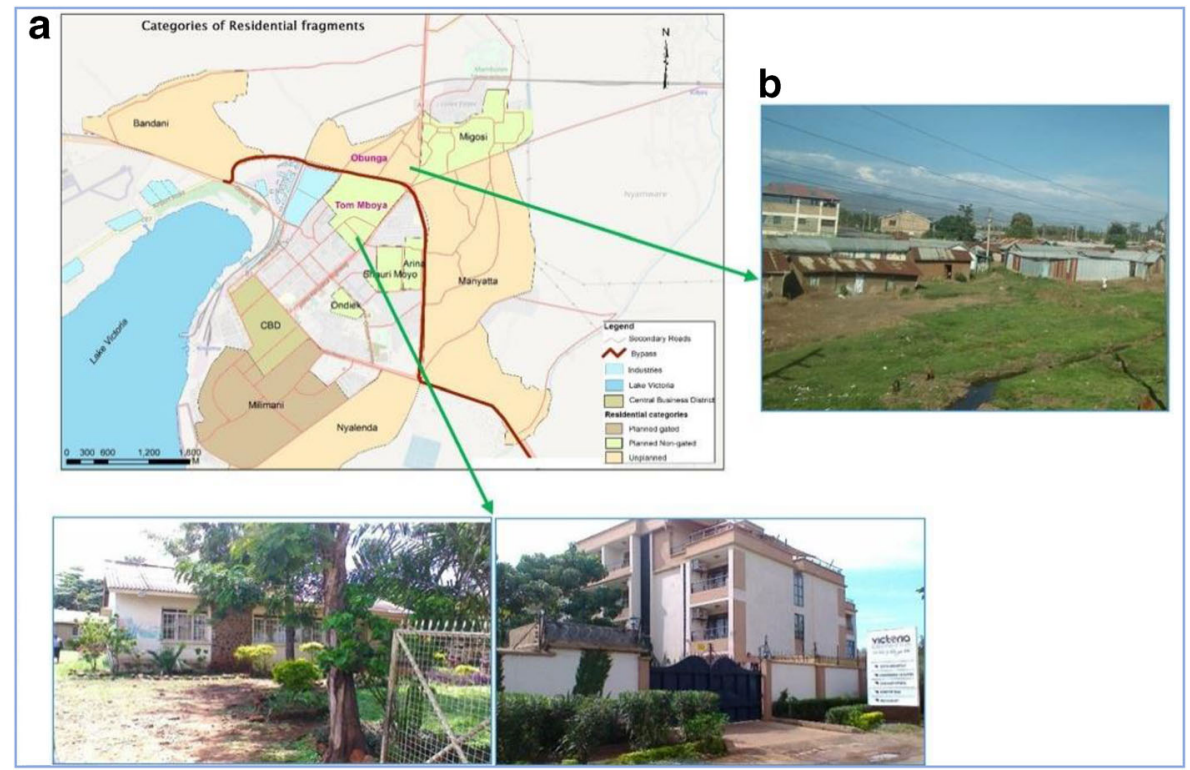

Fig. 3 a Change in land use in Tom Mboya community from residential (left) to commercial-hotel (right). b Change in quality of houses in Obunga community, Kisumu. Source: Authors, 2018, based on field observation 
women in the communities gained employment through the sale of food to road construction workers not only during the road construction but even after, some of them are earning income for their livelihoods through small businesses by the roadside. According to the Physical City Planner of Kasoa in Accra city, confirms that "...the road expansion served as a means for movement of goods and services and security within the town, it therefore brought direct and indirect employable avenues to the residents of the studied communities".

Contrary, the road projects also led to the displacement of some residents in the studied communities. The Kisumu bypass interfered with residents' businesses that were being operated along the road reserve and displaced people during the construction phase, especially in Obunga community. An interview with one of the Obunga residents confirmed an increase in house rents and property values following the bypass construction (Fig. 3b). Further, a replacement with housing typical of higher income groups than those present in the area was observed. This led to the displacement of some of the low-income residents and adversely affected the already established social networks. A resident in Obunga confirmed this; “...The construction of the Bypass has influenced housing. The property value of plots in Obunga has risen because people are seeing the opportunities now and if you check on the designs and quality of the upcoming houses, they are different from what used to be associated with Obunga. People doing this may not be necessarily the Obunga residents..." However, in Tom Mboya community, the increase in property value was realized to have a positive impact because the residents were leasing out their dwellings for commercial use to earn cash. Therefore, the impacts were twofold, on the one hand, the residents could sell and lease land, but on the other, people were being displaced.

In peri-urban Accra, after the road expansion, the property market became vibrant with rents increasing beyond the reach of some residents forcing them to migrate to interior parts. Sale of land or property rentals within the communities was subjected to the market forces, causing the displacement of the poor as property owners were asking higher rents. Also, the chiefs as the traditional authority and original landholders in the communities took advantage of the high land prices to confiscate land parcels granted to the peasant farmers to sell to property developers. Although this benefitted the local authority through tax payment from business setups by the rich in the communities, it affected to some extent the social composition within the communities as the poor were displaced by the rich. Kisumu bypass
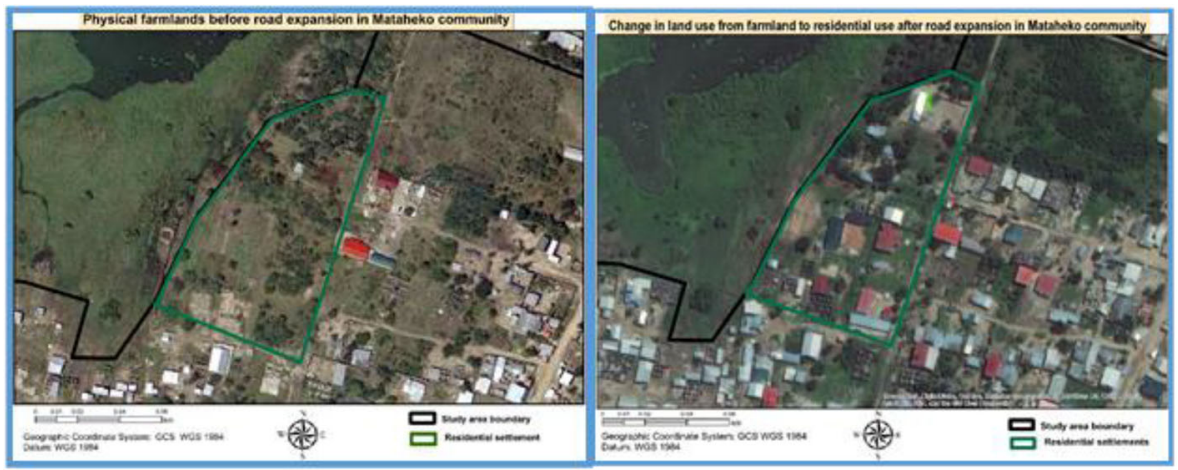

Fig. 4 Farmlands (left) transformed into residential uses (right) in Mataheko after road expansion (Source: Google Earth, 2008 and 2018) 
in the initial development plan of the city existed as a narrow road and so people settled on the road reserves, subdivided land and erected business premises. This revealed that people had encroached on the land earmarked for the road development and this brought conflict during implementation as confirmed by the Obunga residents' association official: "There was conflict between people and the government because people were not paid before construction started. Again there was conflict between people themselves, those who bought land didn't transfer land ownership, this delayed compensation process and some were compensated and never relocated."

With the road expansion, travel time to and from Accra central was reduced. Hence, Kasoa became the residential destination for most high and middle-income earners, and this led to land management problems due to increase in demand for land with several multiple sales of land by some landowners which are hindering development in the area negatively (Table 5). Key informants highlighted that communities along the expanded Accra-Kasoa road were inundated with land disputes over plots of land which adversely scared away potential developers and investors due to activities of land guards.

\section{Discussion}

To understand how road infrastructure projects impact peri-urban areas in Global South cities, this paper relates its findings from the four studied communities in Kisumu and Accra cities to the existing body of literature's perspectives on road infrastructure impacts. The paper has analyzed the impacts of road infrastructure projects in the four communities in the peri-urban areas of both cities, by comparing changes and processes due to the projects concerning social, spatial and economic aspects.

The findings on social interaction measured by social networks of residents varied across the two cities. Findings from Tom Mboya and Obunga communities of Kisumu revealed that intra-neighbourhood interactions improved after road expansion. This aligns with the findings of Lusher et al. (2010); Hoogerbrugge and Burger (2018) and Farahani (2016) on social networks which are fond of augmenting interaction between residents and making one feel at home. In contrast, in Accra, residents in the studied communities perceived a decline in the social integration due to the springing up of gated communities replacing non-gated ones.

In both Kisumu and Accra, improved accessibility to basic facilities and services after implementation of the road projects was noted in the studied communities. In Kisumu, residents of Tom Mboya and Obunga experienced improved access to facilities and services, which may be due to enhanced intra neighbourhood accessibility to facilities, partly due to implementation of the Bypass. In Accra, the impact was mainly an increase in access to potable water due to the laying of water pipelines and drilling of about 20 boreholes in and around Accra. This conforms with what is found in other studies on roads as a means of enhancing socio-economic needs of societies by providing access to basic facilities and services (Pradhan and Bagchi 2013; Gibson and Rozelle 2003).

The findings on the spatial aspect underscore the fact that peri-urban towns in the Global South have become the destination for residential developments, this has been observed to be due to road developments and serves as a vehicle for the increase in land consumption mainly for residential development (Ravetz et al. 2013; Simon et al. 2004; Woltjer 2014) as noted explicitly in Tuba and Mataheko in Accra city. Such road developments are changing 
Table 5 Overview of the positive and negative impacts after the road projects in Kisumu and Accra cities

\begin{tabular}{|c|c|c|c|}
\hline \multirow[t]{2}{*}{ Major dimensions } & \multirow{2}{*}{$\begin{array}{l}\text { Positive impacts } \\
\text { of the roads }\end{array}$} & Kisumu & Accra \\
\hline & & Tom Mboya/Obunga & Tuba /Mataheko \\
\hline Social & $\begin{array}{l}\text { Improved social } \\
\text { interaction }\end{array}$ & $\begin{array}{l}\text { Improved social interaction } \\
\text { between residents and within } \\
\text { own community through social } \\
\text { networks }\end{array}$ & \\
\hline \multirow[t]{2}{*}{ Spatial } & $\begin{array}{l}\text { Improved } \\
\text { accessibility }\end{array}$ & \multicolumn{2}{|c|}{$\begin{array}{l}\text { Easier access to basic facilities and services. } \\
\text { Improved accessibility to both motorized and non-motorized users } \\
\text { (NMU) }\end{array}$} \\
\hline & $\begin{array}{l}\text { Reduction in } \\
\text { travel time } \\
\text { and costs }\end{array}$ & $\begin{array}{l}\text { Connection to other communities } \\
\text { by use of motorcycles and } \\
\text { reduction in traffic jams }\end{array}$ & Reduction in travel time \\
\hline \multirow[t]{2}{*}{ Economic } & $\begin{array}{l}\text { Increase of } \\
\text { employment } \\
\text { opportunities }\end{array}$ & \multicolumn{2}{|c|}{ More job opportunities during and after roads' construction phases } \\
\hline & $\begin{array}{l}\text { Increased } \\
\text { commerce }\end{array}$ & \multicolumn{2}{|c|}{ Improved business activities \& market base in the communities. } \\
\hline Major dimensions & $\begin{array}{l}\text { Negative impacts } \\
\text { of the roads }\end{array}$ & Tom Mboya/Obunga & Tuba /Mataheko \\
\hline \multirow[t]{2}{*}{ Social } & Increase in crime & $\begin{array}{l}\text { Increase in crime rate beneath the } \\
\text { overpasses of the bypass road } \\
\text { to non-motorized users } \\
\text { especially at night }\end{array}$ & $\begin{array}{l}\text { Increase in crime rate of like } \\
\text { robbery, pick pocketing }\end{array}$ \\
\hline & $\begin{array}{l}\text { Decrease in } \\
\text { social } \\
\text { interaction }\end{array}$ & & $\begin{array}{l}\text { Social interactions of residents } \\
\text { between and within } \\
\text { communities decreased }\end{array}$ \\
\hline \multirow[t]{4}{*}{ Spatial } & $\begin{array}{l}\text { Displacement of } \\
\text { people }\end{array}$ & \multicolumn{2}{|c|}{$\begin{array}{l}\text { Displacement of low-income residents by middle income residents. } \\
\text { Increase in land prices and house rent }\end{array}$} \\
\hline & & & $\begin{array}{l}\text { Development of informal } \\
\text { settlements and gated } \\
\text { communities }\end{array}$ \\
\hline & Unregulated & \multicolumn{2}{|c|}{ Residential areas being converted to commercial areas/uses } \\
\hline & $\begin{array}{l}\text { conversion of } \\
\text { land uses }\end{array}$ & & $\begin{array}{l}\text { Change in agricultural Land use } \\
\text { (Loss of farmland). } \\
\text { Development of informal } \\
\text { settlements and gating } \\
\text { communities }\end{array}$ \\
\hline \multirow[t]{2}{*}{ Economic } & $\begin{array}{l}\text { Disruption of } \\
\text { businesses, } \\
\text { customers and } \\
\text { income }\end{array}$ & \multicolumn{2}{|l|}{$\begin{array}{l}\text { Disruption of businesses, } \\
\text { customers \& income during } \\
\text { road construction phase }\end{array}$} \\
\hline & $\begin{array}{l}\text { Conflict in the } \\
\text { area during } \\
\text { road } \\
\text { construction }\end{array}$ & $\begin{array}{l}\text { Some of the compensated } \\
\text { residents refused to relocate, } \\
\text { and this brought conflict } \\
\text { between them and the } \\
\text { government during } \\
\text { implementation of the bypass } \\
\text { road }\end{array}$ & $\begin{array}{l}\text { Increase in demand for land with } \\
\text { several multiple sales of land } \\
\text { by some land owners, led to } \\
\text { conflict between land buyers, } \\
\text { and this hindered development } \\
\text { in the area }\end{array}$ \\
\hline
\end{tabular}


the urban forms of communities near the roads in a distinct mosaic way. In Tom Mboya in Kisumu, the Bypass led to increase in residential densities and conversion of residential to commercial use, whereas in Obunga, improved quality of houses was noted as middleincome residents moved in because of the Bypass, which may be attributed to gentrification. Just as highlighted by Davidson and Lees (2005) on their writing on contemporary gentrification in the Global South, our cases show characteristics of gentrification to include direct and indirect displacement of low-income groups, and social upgrading of locale by incoming high-income groups.

Concerning the economic aspects, this study found that the Kisumu and Accra cities road infrastructure projects led to employment opportunities for residents. The study revealed that more job opportunities were noted during and after the construction phase of the road projects. The Kisumu bypass sparked off the use of motorcycles as commercial transport services and increased commerce, while in Accra, small-scale businesses often operated by female residents along the road improved. However, across the four communities, poor residents were displaced due to an increase in land prices and house rents.

Gentrification in the Global South often happens due to the displacement of lowincome people (poor residents) by the rich with an increase in the rental market forces and urbanization caused by infrastructure developments (López-Morales 2015; Krijnen 2018; Briggs and Mwamfupe 2000). Also our study reveals unregulated conversion of land uses from residential areas to commercial uses, especially in Tom Mboya in Kisumu city. In Accra, however, agricultural lands were converted to residential uses causing the displacement of some households who depended on farming and this adversely affected integration in the studied communities, after the expansion of the roads. Besides, the study revealed the disruption of businesses operating along the road reserve during its construction phase in Kisumu.

To summarise, considering the analysis of the impacts accruing from the subsections of the Kisumu and Accra road infrastructure projects in their peri-urban areas, both positive and negative impacts were noted along the social, spatial and economic dimensions. Findings of the four studied communities indicated that road infrastructure projects led to improved access to facilities and services. Positive effects of the roads on the socio-economic aspects included more job opportunities and improved commerce in all the communities. Also, reduction in travel time in the four communities, with improved connectivity to other communities was observed only in the two communities in Kisumu, but not those in Accra. The road infrastructure projects also brought with them adverse effects. Displacement and insecurity were felt across the four communities; in Tom Mboya and Obunga in Kisumu, specific sections of the overpasses posed a danger to residents especially at night. While in Accra, robbery and pickpocketing were being experienced by residents of Tuba and Mataheko.

\section{Conclusion}

The study aimed to investigate how road infrastructure projects impact peri-urban areas in Kisumu, Kenya and Accra, Ghana. In order to do so, it operationalized its main objective across the studied communities in both cases. It produced empirical findings and conclusions on how road infrastructure projects change the urban fabric and 
associated processes and how they impact different social groups of peri-urban areas in the Global South. As also found in earlier studies, this study has shown that road infrastructure projects come with both positive and negative impacts on different social groups where they are being implemented. In both cities, the completion of the road projects created some common developments in the studied communities: improvement in accessibility, increase in commerce, more employment opportunities and reduction in travel time. However, the road projects brought out some contrasting developments across them as well. The Kisumu road project led to economic and spatial dynamics in Obunga, including disruption of business activities and displacement of people on the road reserves during the construction phase. The Accra road project caused spatial and social impacts, including informal settlements and gated communities to emerge and led to a loss of farmlands in Tuba and Mataheko and also negatively affected integration. The study reveals that road infrastructure projects led to changes in the social fabric, economic processes and spatial differences, meaning that road infrastructure projects have a range of impacts on both the population and urban fabric.

The study has certain limitations. The cases investigated two different moments in time of before and after the construction of road infrastructure projects and the respondents were asked to give responses to both moments. However, evaluation of memory sometimes may lead to a bias of recall, and respondents are likely to remember specific questions and recent memories but not the past. The study analyzed the effects of road infrastructure projects using a case study approach. It is therefore important to carry out further research on more communities adjacent to the road infrastructure projects and assess if the results found in this study are unique or can be generalized.

As the impacts of road infrastructure appear to differ in locational context and class of individuals within peri-urban areas, our research suggests that place-based and people-based policies be combined to address the consequences of road infrastructure projects. More specifically, policies to protect land rights and enforce strategic spatial planning and those that deal with the emerging impacts of road infrastructure projects on different social groups. This study reveals that road infrastructure projects in peri-urban areas have positive implications. However, when looking at community wellbeing, it has a negative impact on livelihoods too. Thus they have the potential to cause both social and functional decompositions in peri-urban areas such as inequality, conflicts, segregation and unplanned developments for policymakers to deal with. Both cases show an indication that the environmental dimension is also an important aspect and may play a role when considering impacts accruing from road infrastructure projects. However, it was not considered in this study, hence the paper recommends this for future research.

Acknowledgements We would like to thank all those who took part in this study, especially those who accepted to be interviewed and Dr. Alexander Follmann for reviewing the manuscript.

Funding This study was funded by the Faculty of Geo-Information Science and Earth Observation of the University of Twente.

\section{Compliance with Ethical Standards}

Conflict of Interest The authors declare that they have no competing interests. 
Open Access This article is licensed under a Creative Commons Attribution 4.0 International License, which permits use, sharing, adaptation, distribution and reproduction in any medium or format, as long as you give appropriate credit to the original author(s) and the source, provide a link to the Creative Commons licence, and indicate if changes were made. The images or other third party material in this article are included in the article's Creative Commons licence, unless indicated otherwise in a credit line to the material. If material is not included in the article's Creative Commons licence and your intended use is not permitted by statutory regulation or exceeds the permitted use, you will need to obtain permission directly from the copyright holder. To view a copy of this licence, visit http://creativecommons.org/licenses/by/4.0/.

\section{References}

Al Shawish, A. (2015). Evaluating the impact of gated communities on the physical and social fabric of Doha City. In 12th International Postgraduate Research Conference (IPGRC15) (pp. 67-79). Manchester (United Kingdom): In-house publication.

Allen, A. (2003). Environmental planning and management of the peri-urban interface: perspectives on an emerging field. Environment and Urbanization, 15(1), 135-148. https://doi.org/10.1630 /095624703101286402.

Anderson, J.D. (2016). The Socioecology of diarrheal disease exposure in peri-urban communities of Kisumu , Kenya (PhD dissertation). ProQuest LLC. Gainesville, Florida: University of Florida.

Aoun, O. (2016). Urban megaprojects-based approach in urban planning: From isolated objects to shaping the City. The case of Dubai. PhD dissertation, Liège: Faculty of Applied Sciences-Université de Liège.

Ardayfio-Schandorf, E., Yankson, P. W. K., \& Bertrand, M. (2012). The Mobile City of Accra: Urban families, housing and residential practices. Dakar. Council for the Development of Social Science Research in Africa.

ASIRT. (2014). Road travel report, republic of Ghana. Road Travel, Rockville, USA: Association for Safe International.

Balbo, M., \& Navez-Bouchanine, F. (1995). Urban fragmentation as a research hypothesis: Rabat-Salé case study. Habitat International, 19(4), 571-582. https://doi.org/10.1016/0197-3975(95)00008-4.

Berhe, R. T., Martinez, J., \& Verplanke, J. (2014). Adaptation and dissonance in quality of life: a case study in Mekelle, Ethiopia. Social Indicators Research, 118(2), 535-554.

Beuran, M., Gachassin, M., \& Raballand, G. (2015). Are there myths on road impact and transport in subSaharan Africa? Development Policy Review, 33(5), 673-700.

Bocarejo, J. P., Portilla, I., \& Meléndez, D. (2015). Social fragmentation as a consequence of implementing a bus rapid transit system in the city of Bogotá. Urban Studies, 53(8), 1617-1634. https://doi.org/10.1177 /0042098015588739.

Bodo, T. (2019). Rapid urbanisation: theories, causes, consequences and coping strategies. Annals of Geographical Studies, 2(3), 32-45.

Briggs, J., \& Mwamfupe, D. (2000). Peri-urban development in an era of structural adjustment in Africa: the city of Dar Es Salaam, Tanzania. Urban Studies, 37(4), 797-809.

Brussel, M., Zuidgeest, M., Pfeffer, K., \& Maarseveen, V. M. (2019). Access or accessibility? A critique of the urban transport SDG indicator. ISPRS International Journal of Geo-Information, 8(67). https://doi. org/10.3390/ijgi8020067.

Bryman, A. (2006). Integrating quantitative and qualitative research: how is it done? Qualitative Research, 6(1), 97-113. Retrieved from http://qrj.sagepub.com/content/6/1/97.abstract. https://doi.org/10.1177 $/ 1468794106058877$.

Bryman, A. (2012). Social research methods (4th ed.). New York: Oxford University Press.

Cobbinah, P. B., Erdiaw-Kwasie, M. O., \& Amoateng, P. (2015). Rethinking sustainable development within the framework of poverty and urbanisation in developing countries. Environmental Development, 13(1), 18-32. https://doi.org/10.1016/j.envdev.2014.11.001.

CRDC. (2016). Kisumusan baseline survey report. Report Submitted to Practical Action, East Africa Regional Office. Kisumu.

Davidson, M., \& Lees, L. (2005). New-build "gentrification" and London's riverside renaissance. Environment and Planning A, 37(7), 1165-1190. https://doi.org/10.1068/a3739. 
Doan, P., \& Oduro, C. Y. (2012). Patterns of population growth in peri-urban Accra, Ghana. International Journal of Urban and Regional Research, 36(6), 1306-1325. https://doi.org/10.1111/j.14682427.2011.01075.x.

Erkul, M., Yitmen, I., \& Çelik, T. (2016). Stakeholder engagement in mega transport infrastructure projects. Procedia Engineering, 161(1), 704-710. https://doi.org/10.1016/j.proeng.2016.08.745.

Farahani, M. L. (2016). The value of the sense of community and neighbouring. Housing, Theory and Society, 33(3), 357-376. https://doi.org/10.1080/14036096.2016.1155480.

Gachassin, M., Najman, B., \& Raballand, G. (2010). The impact of roads on poverty reduction a case study of Cameroon (5209). The World Bank Africa Region Transport Unit: Toulouse.

Gibson, J., \& Rozelle, S. (2003). Poverty and access to roads in Papua New Guinea. Economic Development and Cultural Change., 52, 159-185. https://doi.org/10.1086/380424.

Gichaga, F. J. (2017). The impact of road improvements on road safety and related characteristics. IATSS Research, 40(2), 72-75. https://doi.org/10.1016/j.iatssr.2016.05.002.

Grant, R., \& Yankson, P. (2003). City profile Accra. Cities, 20(1), 65-74. https://doi.org/10.1016/S0264-2751 (02)00090-2.

Hoogerbrugge, M. M., \& Burger, M. J. (2018). Neighborhood-based social capital and life satisfaction: the case of Rotterdam, the Netherlands. Urban Geography, 39(10), 1484-1509. https://doi.org/10.1080 /02723638.2018.1474609.

Huby, M., Cinderby, S., White, P., \& De Bruin, A. (2009). Measuring inequality in rural England: the effects of changing spatial resolution. Environment and Planning A, 41, 3023-3038. https://doi.org/10.1068/a425.

Jedwab, R., \& Moradi, A. (2016). The permanent effects of transportation revolutions in poor countries: evidence from Africa. Review of Economics and Statistics, 98(2), 268-284. https://doi.org/10.1162 /REST_a_00540.

Jedwab, R., Kerby, E., \& Moradi, A. (2017). History, path dependence and development: evidence from colonial Railways, settlers and cities in Kenya. Economic Journal, 127, 1467-1494. https://doi. org/10.1111/ecoj.12347.

Kennedy, L. (2015). The politics and changing paradigm of megaproject development in metropolitan cities. Habitat International, 45(P3), 163-168. https://doi.org/10.1016/j.habitatint.2014.07.001.

Kola, M. O., Onyango, G. M., \& Oindo, B. O. (2015). Factors determining land use development in the unplanned suburbs of Kisumu municipality, Kenya. International Journal of Arts and Commerce, 1(1), 24.

Kombe, W. J. (2005). Land use dynamics in peri-urban areas and their implications on the urban growth and form: the case of Dar Es Salaam, Tanzania. Habitat International, 29, 113-135. https://doi.org/10.1016 /S0197-3975(03)00076-6.

Krijnen, M. (2018). Gentrification and the creation and formation of rent gaps: opening up gentrification theory to global forces of urban change. City, 22(3), 437-446. https://doi.org/10.1080 /13604813.2018.1472461.

Landman, K. (2011). Urban fragmentation: Different views on its causes and consequences. In Internal Handbook of Urban Policy: Issues in the Developing World. Cheltenham: Edward Elgar Publishing.

Leinbach, T. R. (2000). Mobility in development context: changing perspectives, new interpretations, and the real issues. Journal of Transport Geography, 8, 1-9.

López-Morales, E. (2015). Gentrification in the global south. City Analysis of Urban Trends, Culture, Theory, Policy, Action, 19(4), 564-573. https://doi.org/10.1080/13604813.2015.1051746.

Lusher, D., Robins, G., \& Kremer, P. (2010). The application of social network analysis to team sports. Measurement in Physical Education and Exercise Science, 14(4), 211-224. https://doi.org/10.1080 /1091367X.2010.495559.

Mackett, R. L., \& Edwards, M. (1998). The impact of new urban public transport systems: will the expectations be met? Transport Research Part A: Policy and Practice, 32(4), 231-245. https://doi. org/10.1016/S0965-8564(97)00041-4.

Manderscheid, K., \& Bergman, M. (2008). Spatial patterns and social inequality in Switzerland?: Modern or post-modern? In The social fabric of the networked city (pp. 41-65). Lausanne: EPFL Press.

Martínez, J. A. (2009). The use of GIS and indicators to monitor intra-urban inequalities. A case study in Rosario, Argentina. Habitat International, 33(4), 387-396. https://doi.org/10.1016/j. habitatint.2008.12.003.

Oviedo Hernandez, D., \& Dávila, J. D. (2016). Transport, urban development and the peripheral poor in Colombia - Placing splintering urbanism in the context of transport networks. JTRG, 51, 180-192. https://doi.org/10.1016/j.jtrangeo.2016.01.003.

Porter, G. (2011). 'I think a woman who travels a lot is befriending other men and that's why she travels': mobility constraints and their implications for rural women and girls in sub-Saharan Africa. Gender, Place and Culture, 18(1), 65-81. https://doi.org/10.1080/0966369X.2011.535304. 
Pradhan, R. P., \& Bagchi, T. P. (2013). Effect of transportation infrastructure on economic growth in India: the VECM approach. Research in Transportation Economics, 38, 139-148. https://doi.org/10.1016/j. retrec.2012.05.008.

Ravetz, J., Fertner, C., \& Nielsen, T. S. (2013). The dynamics of Peri-urbanization. In K. Nilsson et al. (Eds.), Peri-urban futures: Scenarios and models for land use change in Europe. Verlag Berlin Heidelberg: Springer-Berlin Heidelberg. https://doi.org/10.1007/978-3-642-30529-0_2.

Ruiz-Tagle, J. (2013). A theory of socio-spatial integration: problems, policies and concepts from a US perspective. International Journal of Urban and Regional Research, 37(2), 388-408. https://oi. org/10.1111/j.1468-2427.2012.01180.x.

Sabatini, F. (2006). The social spatial segregation in the cities of Latin America. Washington, D.C: InterAmerican DEPARTMENT Bank, Sustainable Development Department, Social Programs Division.

Sabatini, F., \& Salcedo, R. (2007). Gated communities and the poor in Santiago, Chile: functional and symbolic integration in a context of aggressive capitalist colonization of lower-class areas. Housing Policy Debate, 18(3), 577-606.

Senlier, N., Yildiz, R., \& Aktas, E. D. (2009). A perception survey for the evaluation of urban quality of life in Kocaeli and a comparison of the life satisfaction with the European cities. Social Indicators Research, 94(2), 213-226. https://doi.org/10.1007/s11205-008-9361-1.

Simon, D., McGregor, D., \& Nsiah-Gyabaah, K. (2004). The changing urban-rural interface of African cities: definitional issues and an application to Kumasi, Ghana. Environment Urbanization 16(2): 235-248. Retrieved from http://journals.sagepub.com/doi/pdf/10.1177/095624780401600214

Thuo, A.D.M. (2010). Community and social responses to land use transformations in the Nairobi ruralurban fringe, Kenya. Field actions science report for the special issue 1-urban agriculture. Hamilton, New Zealand.

UN-Habitat. (2016). Urbanization and development: Emerging futures. Nairobi, Kenya.

Wagah, G., Mwehe, M., Obange, N., Teyie, P., \& Nystrom, M. (2017). Land tenure systems in Kisumu City; the formal-informal dichotomy. International Journal of Sciences, 6(10), 32-42. https://doi.org/10.18483 /ijSci.1450.

Wiegand, M., Koomen, E., Pradhan, M., \& Edmonds, C. (2017). The impact of road development on household welfare in rural Papua New Guinea (no. TI 2017-076/V). Amsterdam and Rotterdam, Tinbergen Institute.

Woltjer, J. (2014). A global review on Peri-urban development and planning. Journal Perencanaan Wilayah Dan Kota, 25(1), 1-16.

Yankson, P. W. K., \& Gough, K. V. (1999). The environmental impact of rapid urbanization in the periurban area of. Geografisk Tidsskrift-Danish Journal of Geography, 99(1), 89-100. https://oi.org/10.1080 /00167223.1999.10649426org/10.1080/00167223.1999.10649426.

Publisher's Note Springer Nature remains neutral with regard to jurisdictional claims in published maps and institutional affiliations.

\section{Affiliations}

\section{Risper Sarah Khanani ${ }^{1} \cdot$ Emmanuel Junior Adugbila ${ }^{1} \cdot$ Javier A. Martinez ${ }^{1} \cdot$ Karin $^{-}$ Pfeffer $^{1}$}

Risper Sarah Khanani

khanani11577@alumni.itc.nl

Emmanuel Junior Adugbila

e.j.adugbila@utwente.nl

Karin Pfeffer

k.pfeffer@utwente.nl

1 Department of Urban and Regional Planning and Geo-Information Management, Faculty of GeoInformation Science and Earth Observation (ITC), University of Twente, Enschede, The Netherlands 